Equalita, Vol. 2 Issue 1, Juni 2020

Avaliable online at http://syekhnurjati.ac.id/jurnal/index.php/equalita/article/view/6417

Diterbitkan oleh Pusat Studi Gender dan Anak LP2M IAIN Syekh Nurjati Cirebon, Indonesia

\title{
PENGARUH KEPEMIMPINAN KEPALA SEKOLAH PEREMPUAN DAN KINERJA GURU DI MADRASAH TSANAWIYAH
}

\section{Asep Kurniawan*}

asepkurniawan@syekhnurjati.ac.id

IAIN Syekh Nurjati Cirebon

- Received: 30 April 2020

-Accepted: 30 April 2020 •Published online: 30 Juni 2020

\begin{abstract}
:
Efektivitas dari kepemimpinan kepala sekolah adalah diantara faktor dari sejumlah faktor yang berkaitan dengan kinerja guru, melalui kinerja yang baik, maka proses komunikasi pendidikan di suatu sekolah akan terlaksana dengan baik. Penelitian ini bertujuan untuk mengungkap sejauhmana pengaruh kepemimpinan kepala sekolah perempuan terhadap kinerja guru di MTsN Ciledug Cirebon. Metode penelitian ini ialah kuantitatif korelasional. Populasi penelitian adalah 67 guru dengan sampel 30 guru. Instrumen yang dipergunakan adalah angket. Teknik analisis yang dipakai ialah teknik analisis Statistik Parametris sebagaimana jenis penelitian bersifat asosiatif, dengan memakai korelasi bivariate atau Product Moment Pearson. Hasil yang memperlihatkan bahwa ada hubungan yang sangat kuat antara Variabel Kepemimpinan Kepala Sekolah perempuan (X), dengan Kinerja Guru di MTsN Ciledug Cirebon sebesar 0,825 atau memiliki pengaruh langsung sebesar 68,0625\%. Hal tersebut berarti apabila kepemimpinan Kepala Sekolah perempuan sudah baik, maka kinerja guru pun menjadi baik.
\end{abstract}

Kata kunci: Kepemimpinan; Perempuan; Kinerja; Guru.

\begin{abstract}
The effectiveness of the principal's leadership is one of the factors related to teacher performance. With good performance, the educational communication process in a school will be implemented well. This study aimed to reveal the extent of the influence of the leadership of female principals on teacher performance in State Islamic Junior High School Ciledug Cirebon. This research method was a quantitative correlational. The study population was 67 teachers with a sample of 30 teachers. The instruments used were questionnaires. The analysis technique used was the Parametric Statistical analysis technique as the type of research is associative through bivariate correlation or Pearson Product Moment. The results showed that there was a very strong relationship between the female school principals' leadership variable (X), the teacher's performance in State Islamic Junior School Ciledug Cirebon, which was 0.825 or has a direct influence of $68.0625 \%$. It means that if the leadership of the female headmaster was good, the teacher's performance would be good.
\end{abstract}

Keywords: Leadership; women; performance; teacher.

${ }^{*}$ Corresponding Author, Email: asepkurniawan@syekhnurjati.ac.id 


\section{A. PENDAHULUAN}

Kepemimpinan adalah kunci utama keberhasilan suatu organisasi yang dipimpinnya (Văcar dan Miricescu, 2013: 430-435). Seorang pemimpin harus mempunyai kompetensi kepemimpinan. Dalam sistem manajemen pendidikan di Indonesia, kompetensi kepemimpinan diatur melalui Peraturan Menteri Pendidikan Nasional No. 13 Tahun 2007 mengenai Standar Kepala Sekolah atau Madrasah diputuskan bahwa ada lima dimensi kompetensi, yakni kompetensi sosial, kompetensi supervisi, kompetensi kewirausahaan, kompetensi manajerial, dan kompetensi kepribadian. Sebagai pemimpin, kepala sekolah mempunyai tanggungjawab formal untuk mengembangkan kurikulum, para pegawai, dan jalannya pendidikan di sekolahnya seperti yang termuat dalam Peraturan Menteri Pendidikan Nasional No. 19 Tahun 2007 mengenai Standar Pengelolaan Pendidikan Dasar dan Menengah.

Membahas mengenai kepemimpinan perempuan ada hubungannya dengan mendiskusikan tentang persoalan gender dengan titik tekan pada posisi perempuan di berbagai lini kehidupan, mulai dari pandangan yang menghawatirkan ketidakadilan laki-laki terhadap perempuan sampai dengan kepatutan perempuan dalam tugas-tugas masyarakat. Wanita acapkali diidentikkan dengan kelemahan, kelembutan, dan kelas sosial. Oleh karena itu, diskriminasi senantiasa terjadi sebab wanita dipandang tidak lebih dapat melakukan banyak hal yang dapat dilakukan oleh laki-laki (Rosida dan Rejeki, 2017: 129; Channar, et al, 2011: 177-191).

Padahal, kepemimpinan perempuan dinilai dapat menyelesaikan beberapa persoalan dalam dunia pendidikan. Fenomena demikian sudah banyak memperlihatkan bahwa perempuan telah banyak yang menempati jabatan sebagai pemimpin, seperti sebagai presiden, menteri, direktur rumah sakit, pimpinan perusahaan, kepala sekolah, kepala kantor, kepala desa, dan sebagainya. Akan tetapi, proporsi kepemimpinan perempuan tersebut jika dibandingkan secara keseluruhan populasi perempuan, masih lebih kecil dibandingkan dengan proporsi laki-laki sebagai pemimpin. Kenyataan yang lain yang berhubungan dengan prosentase perempuan dalam usaha dan angkatan kerja dapat dilihat dengan munculnya banyak pemimpin perempuan di zaman pemerintahan Jokowi, seperti sebagai menterinya (Nurlina, 2015: 169). Oleh karena itu, peran perempuan dalam kepemimpinan tidaklah suatu hal yang asing lagi. Istilah dalam 
Asep Kurniawan

kesetaraan gender dinamakan dengan kesetaraan peran laki-laki dan perempuan dalam memperoleh sejumlah haknya sebagai makhluk sosial.

Disamping itu, wanita sebagai pemimpin sudah berlangsung khususnya pada pekerjaan di bidang usaha-usaha kesejahteraan sosial, keperawatan, dan akademis. Sejumlah perempuan usia pada rentan 15 tahun ke atas dari pada laki-laki usia 15 tahun ke atas pada periode 2015-2019 memperlihatkan semakin terbukanya lebar kesempatan kepada perempuan sebagai pemimpin dan berperan dalam penyusunan keputusan. Akan tetapi, survey yang dilaksanakan oleh UNDP dalam Jurnal Management of Education (Halilah, 2010: 1) mengenai perilaku dan pandangan terhadap peran serta perempuan secara politis, ekonomi, dan sosial menunjukkan bahwa 77,6\% responden laki-laki ataupun perempuan menganggap bahwa laki-laki mesti sebagai pembuat keputusan dan pemimpin masyarakat.

Adapun saat perempuan diberikan kepercayaan menempati posisi kepemimpinan, terutama kepada sekolah, lahirlah berbagai penilaian miring tentang mutu kepemimpinannya (Johnson, 2008: 39-60). Mulai dari paradigma yang sudah mengakar kuat bahwa perempuan adalah makhluk yang lemah, khususnya dalam pengambilan keputusan, sampai pada persoalan karakter dasar menjadi isu penting pemasungan perempuan untuk unjuk mutu dan berkarir. Dengan demikian hal tersebut, memperlihatkan bahwa masih ada sejumlah masyarakat yang masih ragu-ragu terhadap kapabilitas perempuan dalam memimpin.

Kiprah perempuan dalam lembaga pendidikan bagaikan dua sisi mata uang yang sangat dilematis. Di satu sisi perempuan berjuang sedemikian rupa untuk mewujudkan dan mengoptimalkan kapasitas, sehingga hak dan pengakuan dapat diperoleh. Di lain pihak, ada sejumlah pihak yang masih menyudutkan dan memperdebatkan posisi wanita. Menurut Hejase, et al, (2013:29) dan Carli (1999:81-99) mengatakan bahwa perempuan kurang kompeten sebagai pemimpin. Gaya kepemimpinan perempuan banyak menjiplak laki-laki dalam memimpin, sehingga kepemimpinan perempuan disangsikan. Sementara itu, Fischbach dan Lichtenthaler menjelaskan bahwa pemimpin perempuan dalam menentukan keputusan lebih mengarah pada perasaan sehingga dapat menghambat keberhasilan kepemimpinan perempuan (2015: 153). Perdebatan ini sangat berbeda dengan faktanya, meskipun pemimpin perempuan berupaya untuk berkiprah ke dalam dan keluar tetap dinilai negatif yang memunculkan keragu-raguan dan ketidakpercayaan. Penulis rasa ini hanya berupa perspektif saja, mengutip dari riset Underdahl, Walker dan Woehr (2014:1131) bahwa dalam organisasi yang didominasi 
pria, wanita akan dianggap sebagai pemimpin yang kurang efektif daripada pria, dan begitu pula dalam organisasi yang didominasi wanita, pria akan dianggap sebagai pemimpin yang kurang efektif daripada wanita.

Sementara itu kaitannya dengan dunia pendidikan, budaya birokrasi ternyata masih memposisikan perempuan pada tempat yang tidak menguntungkan, terutama dalam penentuan kebijakan (Hunawa, 2018: 25). Hal tersebut dibuktikan dengan minimnya proporsi perempuan yang menempati posisi sebagai pejabat struktural ataupun fungsional, baik itu tingkat strategis ataupun pada tingkat operasional. Terutama di Kabupaten Cirebon, proporsi kepala sekolah perempuan pada Madrasah Tsanawiyah masih terbilang minim, sebut saja satu-satunya di Kabupaten Cirebon ialah kepala MTsN Ciledug Cirebon. Dengan kata lain, kompetensi kepemimpinan seorang perempuan sebagai kepala sekolah khususnya dalam pemberdayaan bawahan masih disangsikan. Sikap skeptis pejabat berwenang dan pemerintah inilah yang selanjutnya berdampak pada sejumlah keputusan yang diambil khususnya dalam bidang pendidikan kurang memperoleh masukan dari perempuan, sehingga kebijakan-kebijakan yang dihasilkan cenderung kurang memperdulikan persamaan gender.

Padahal kalau mau jujur, perempuan memiliki peran yang cukup strategis dalam keluarga ataupun masyarakat. Kepemimpinan perempuan dipandang dapat menuntaskan sejumlah permasalahan dalam bidang pendidikan. Gupton (2009:1) menerangkan bahwa jalan menuju karir kepemimpinan bagi perempuan dimulai melalui pendidikan. Perempuan yang mempunyai pendidikan yang tinggi bisa menentukan sejumlah alternatif pekerjaan yang sekarang terbuka lebar baginya, contohnya menjabat sebagai kepala sekolah, manajer, bahkan presiden, dan lain-lain.

Perempuan dipandang mempunyai kelebihan untuk menjadi pemimpin yang sukses dalam suatu organisasi atau lingkungan, yang didapatkan secara alamiah ataupun yang terbentuk dari pola asuh. Hasil penelitian Catalyst di Amerika dalam Frankel (2006) menjelaskan bahwa meskipun perempuan adalah 46,4\% dari tenaga kerja, hanya terdapat 8 CEO perempuan di perusahaan katagori Fortune 500. Hanya terdapat 5,2\% perempuan yang dikatagorikan dalam jajaranorang yang berpendapatan tertinggi dan hanya 7,9\% yang menduduki jabatan tertinggi dalam sejumlah perusahaan itu. Akan tetapi, isyarakat terhadap adanya perubahan yang baik diperlihatkan oleh riset Catalyst yang lain, yang memperoleh bahwa perusahaan dengan jabatan manajemen senior sebagian besar diemban oleh perempuan memiliki keuntungan atas ekuitas 35\% 
lebih tinggi, dan total laba atas investasi pemegang saham 34\% lebih tinggi (Hayati, 2009: 2014-215).

Dengan demikian, sudah sepatutnya perempuan diberikan kesempatan dan memperoleh kepercayaan sebagai seorang pemimpin, terutama dalam kasus ini adalah sebagai kepala sekolah dengan harapan agar permasalahan-permasalahan terhadap rendahnya kualitas pendidikan di Tanah Air ini dapat terpecahkan dengan gaya kepemimpinan perempuan, keberhasilan perempuan memimpin sebab gayanya yang non tradisional, yaitu kepemimpinan perempuan lahir dari harapan untuk melakukan apa yang mereka kehendaki atau memiliki kontrol terhadap dirinya sendiri, tidak menilai jabatan kepemimpinan sebagai kendali dan perintah, namun lahir dari kesetiaan dan kepatuhan melalui pemahaman dan pemenuhan kebutuhan orang lain. Dalam arti model kepemimpinan perempuan berpijak pada nilai.

Nilai menjadikan hakikat tentang cara perempuan mempraktekkan perilaku kepemimpinan sehari-hari, mulai dari pengembangan visi, penciptaan tim yang berkinerja tinggi dan mengambil risiko. Frankel (2007:19) menjelaskan bahwa ada sejumlah nilai yang menjadi model kepemimpinan perempuan. Ia berpendapat bahwa model kepemimpinan yang dibutuhkan sekarang ini, yaitu penentu arah kebijakan, penggerak orang lain, pembangun tim, pengambil resiko, motivator, dan pencerdas emosi.

Pendidikan ialah upaya dan terencana untuk menciptakan kondisi pembelajaran yang efektif agar siswa mampu mengembangkan potensi-potensinya untuk mempunyai kekuatan akhlak, keimanan, kecerdasan, dan keterampilan yang dibutuhkan dirinya, masyarakat, bangsa dan negara. Untuk memperoleh yang diharapkan tersebut, para siswa dapat memperolehnya dari guru di lembaga pendidikan, sebab ia mengembangkan potensi siswa agar terbentuk sejalan dengan apa yang sudah dijelaskan diatas. Artinya guru berkontribusi penting dalam menghasilkan siswa yang bermutu, walaupun tidak lepas pula dari upaya-upaya kepala sekolah, wakil kepala sekolah, guru, staf administrasi, orang tua, komite sekolah dan masyarakat (stakeholders).

Terutama hal ini yang memiliki peran yang sangat penting dalam membawa sekolah menjadi lembaga pendidikan yang bermutu ialah pemimpinnya, yaitu kepala sekolah. Lembaga pendidikan yang bermutu tidak terlepas dari kinerja gurunya, karena dia yang langsung berhadapan dengan peserta didik. Oleh karena itu, kepala sekolah merupakan orang yang berpengaruh dan memiliki sejumlah kebijakan sekolah serta 
merupakan orang yang mengarahkan sekolah kepada tujuan tertentu. Oleh karena itu, kepala sekolah adalah diantara komponen pendidikan yang memiliki peran dalam memajukan pendidikan. Seperti diungkapkan dalam sejumlah penelitian bahwa kualitas kepala sekolah sangat berhubungan dengan dengan sisi kehidupan sekolah seperti budaya sekolah (Engels, 2018:159), iklim disiplin, dan disiplin sekolah (Kiprop, 2016: 17) serta kinerja guru (Gewasari, et al, 2017:12; Werang, 2014:635).

Sebagaimana yang sudah dijelaskan guru berperan penting dalam kemajuan pendidikan. Guru merupakan diantara komponen pendidikan yang mesti dituntut bermutu dalam memberi pelayanan maksimal terutama kepada siswa. Mereka ditempatkan pada posisi sentral dan garda terdepan di dalam proses pembelajaran yang mesti dapat mempersiapkan perangkat pembelajaran dengan mendesain kondisi belajar yang aktif dan menyenangkan. Mereka pun mesti menguasai materi pembelajaran dan tahu dengan sebenarnya mengenai karakter dan kemampuan siswanya. Berhubungan dengan itu, maka guru akan menjadi bahan pembicaraan sejumlah orang dan khususnya yang berhubungan dengan kinerja dan totalitas loyalitas serta dedikasi pengabdiannya. Sorotan tersebut lebih mengarah kepada ketidakmampuan guru dalam penyelenggarakan proses pembelajaran sehingga berakhir pada menurunnya mutu pendidikan.

Disamping itu, seorang guru juga mesti dapat bersosialisasi dengan baik kepada teman-temanya sesama guru utamanya dengan pimpinannya. Saat mereka mesti bekerja dalam kondisi lingkungan yang kurang kondusif, maka secara otomatis kinerja yang disampaikan akan kurang optimal. Oleh karena itu, bukanlah sesuatu yang aneh saat masih didapati guru yang beralasan terhadap ketidaksiapan perangkat pembelajaran serta ketidakhadiran atau keterlambatannya di tempat tugas disebabkan oleh sikap pimpinan yang dianggapnya tidak disiplin. Sejauh ini dipersoalkan mengenai kiprah dan potensi perempuan, hakekatnya adalah perempuan mempunyai persoalan dalam memimpin. Bahkan kuatnya kapasitas yang dimiliki perempuan tidak menjadi jaminan kesuksesan pemimpin perempuan dalam manajemen pendidikan di sekolah. Hal tersebut, harus dikaji secara dan dianalisa secara mendalam mengenai bagaimana sesungguhnya kepemimpinan perempuan dari sisi perempuan sebagai pemimpin dan para bawahannya khususnya kaum pria yang merasakan langsung akan kepemimpinannya. Sejumlah fenomena tersebut melahirkan ketertarikan bagi penulis untuk mengkaji sejauh mana kepemimpinan kepala sekolah perempuan di MTsN Cilidug Kabupaten Cirebon berpengaruh terhadap kinerja para gurunya. 


\section{B. METODOLOGI PENELITIAN}

Penelitian ini memakai metode penelitian kuantitatif. Metode penelitiannya ini bersifat fungsional mempunyai tujuan, yakni memahami variabel bebas terhadap variabel terkait. Teknik penelitian ini memakai teknik survey, yakni penelitian yang mengambil tehnik sampling dari suatu populasi dengan memakai angket sebagai instrumen pengumpulan data yang pokok untuk menelaah fenomena atau gejala yang diamati. Populasi penelitian adalah 67 guru dengan sampel 30 guru. Lokasi penelitian dilakukan di Madrasah Tsanawiyah Negeri Ciledug yang beramat di Jl. Letjend. S. Parman Pabuaran Ciledug, Kabupaten Cirebon sejak 5 Januari sampai 30 Maret 2019. Teknik analisis yang dipakai ialah teknik analisis Statistik Parametris sebagaimana jenis penelitian bersifat asosiatif, dengan memakai korelasi bivariate atau Product Moment Pearson. Koefisien ini mengukur keterkaitan antara sejumlah hasil pengamatan dari populasi yang memiliki dua variabel berskala interval atau rasio (Kurniawan, 2018: 273). Perhitungan tersebut menunjukkan bahwa populasi asal sampel memiliki dua variabel dan berdistribusi normal. Formula statistik korelasi bivariate dimaksudkan guna menguji hubungan antara kepemimpinan kepala sekolah perempuan terhadap kinerja guru. Dalam penelitian ini, penulis memakai dua uji pemeriksaan keabsahan data, yakni uji validitas dan realibilitas. Adapun teknik yang dipakai ialah teknik korelasi Product Moment (Noor, 2011). Selanjutnya keajegan pengukuran dengan menggunakan Alfa Cronbach ialah koefisien keajegan yang memperlihatkan seberapa baiknya butir atau item dalam suatu kumpulan secara positif berkorelasi antar satu dengan yang lain (Noor, 2011). Uji realibilitas pada penelitian ini dianalisis memakai Statistical Package For Social Science (SPSS) versi 24.0, yaitu Realibility Analysis.

Adapun operasionalisasi variabel penelitian disajikan pada Tabel 1.

Tabel 1. Operasionalisasi Variabel Penelitian

\begin{tabular}{|c|c|c|}
\hline VariabeI & $\underset{\text { nsi }}{\text { Dime }}$ & Tndikator \\
\hline \multirow{4}{*}{$\begin{array}{l}\text { Kepemimpinan } \\
\text { Kepala Sekolah } \\
\text { Perempuan }\end{array}$} & \multirow[t]{2}{*}{$\begin{array}{l}\text { 1. Kemampuan } \\
\text { Pendidikan }\end{array}$} & $\begin{array}{l}\text { a. Membangun lingkungan belajar yang } \\
\text { hidup, menantang, nyaman dan } \\
\text { menyenangkan }\end{array}$ \\
\hline & & $\begin{array}{l}\text { b. Mengkaji perkembangan pengetahuan di } \\
\text { bidang pengajaran dan pembelajaran, } \\
\text { kurikulum dan penilaian }\end{array}$ \\
\hline & 2. Kemampuan Personal & $\begin{array}{l}\text { a. Kematangan emosional } \\
\text { b. Bersikap sabar, tekun dan teguh }\end{array}$ \\
\hline & $\begin{array}{l}\text { 3. Kemampuan } \\
\text { Relasional }\end{array}$ & $\begin{array}{l}\text { a. Menciptakan lingkungan kerja yang } \\
\text { dinamis dan suportif dimana orang dapat } \\
\text { saling bekerja sama dan saling perhatian }\end{array}$ \\
\hline
\end{tabular}




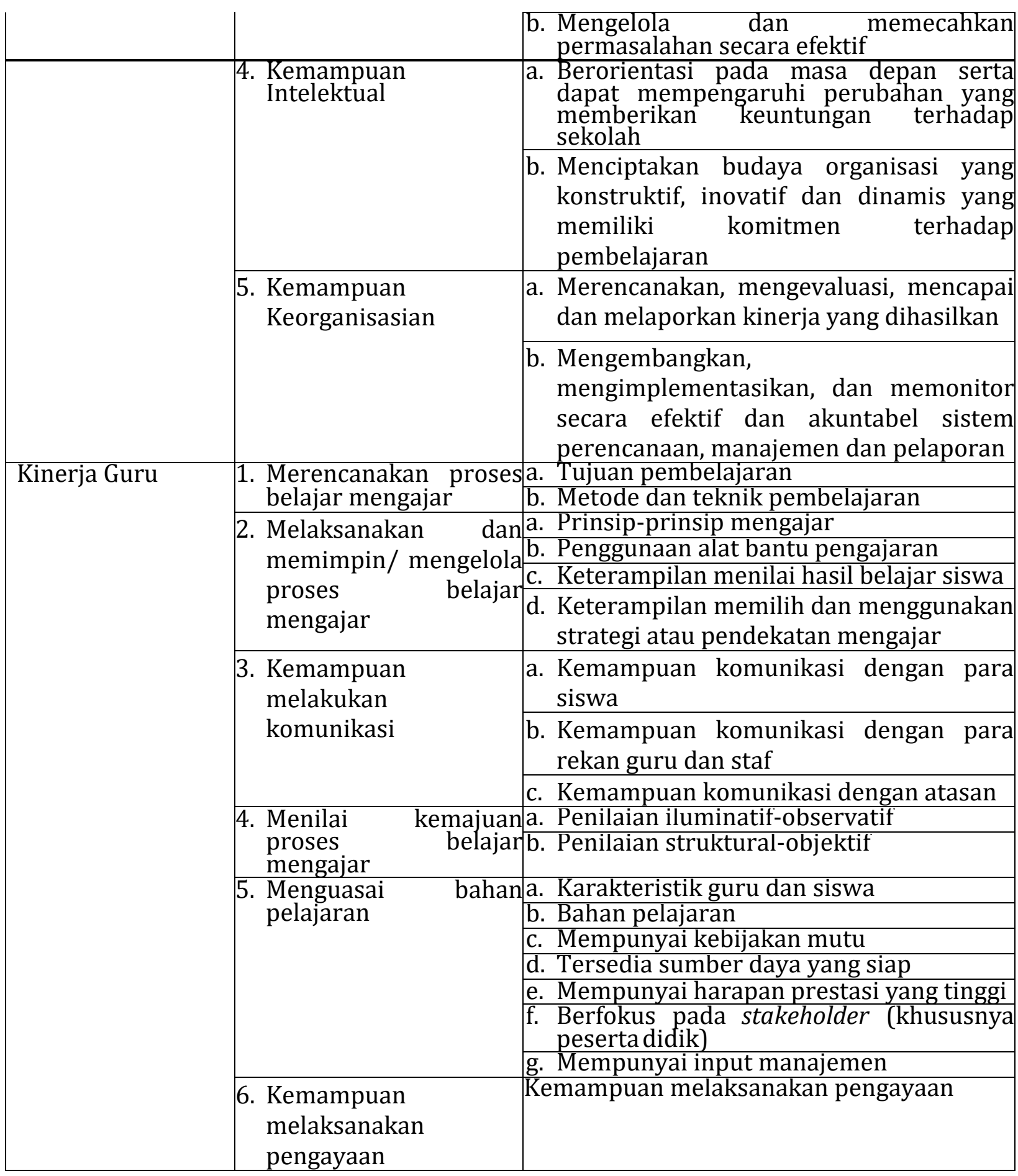

\section{RESULT AND DISCUSSION}

1. Kepemimpinan Kepala Sekolah Perempuan

Kepemimpinan kepala sekolah perempuan adalah suatu tindakan yang dilaksanakan olehnya untuk mengkoordinasikan dan menggerakkan guru yang tergabung dalam MTsN Ciledug Cirebon untuk mencapai tujuan yang sudah ditentukan sebelumnya. Uraian mengenai hasil jawaban responden dalam menilai Kepemimpinan Kepala sekolah perempuan MTsN Ciledug Cirebon melalui sejumlah sub variabel dan meliputi indikator, yaitu: 


\section{Tabel 1}

Jawaban Responden dari Kepemimpinan Kepala Sekolah Perempuan

\begin{tabular}{|l|c|}
\hline \multicolumn{1}{|c|}{ Dimensi Kepemimpinan } & Nilai Rata-rata \\
\hline 1. Kemampuan personal & 4.21 \\
\hline 2. Kemampuan Pendidikan & 4.36 \\
\hline 3. Kemampuan intelektual & 4.39 \\
\hline 4. Kemampuan keorganisasian & 4.43 \\
\hline Jumlah total & 4.39 \\
\hline
\end{tabular}

Berlandaskan pada tabel di atas untuk nilai rata-rata tertinggi berada pada dimensi personal yang artinya Kepala sekolah perempuan MTsN Ciledug Cirebon mempunyai personaliti yang cukup kuat dalam memimpin dan menggerakan para guru yang berada di wilayah otoritasnya. Selanjutnya untuk nilai rata-rata yang terendah berada pada dimensi kemampuan keorganisasian. Dalam hal ini, kepala sekolah perempuan MTsN Ciledug Cirebon memiliki kemampuan keorganisasian yang dikatagorikan cukup dalam merencanakan, mengevaluasi, mencapai dan melaporkan kinerja yang dihasilkan oleh dirinya dan para guru serta staf. Selain itu dia memiliki kemampuan yang cukup dalam mengembangkan, menerapkan, dan memonitor secara akuntabel dan efektif sistem perencanaan, manajemen dan pelaporan terhadap kerja para bawahan.Disamping itu, Kepala sekolah perempuan MTsN Ciledug Cirebon memiliki kemampuan menggerakan para bawahannya, yaitu para guru, staf dan peserta didik bisa melaksanakan ibadah di sekolah terutama dalam tadarus al-Qur'an dan shalat berjama'ah dhuhur.

Apabila ditinjau semua jawaban para responden tentang kepemimpinan kepala sekolah perempuan MTsN Ciledug Cirebon berada di level yang cukup tinggi. Hal tersebut memperlihatkan bahwa kepala sekolah perempuan MTsN Ciledug Cirebon sudah melakukan tugasnya dengan cukup profesional dan baik sejalan dengan aturan perundang-undangan yang berlaku dan tata tertib yang sudah disetujui bersama antara pihak guru, peserta didik, dan komite sekolah. Kepala sekolah perempuan MTsN Ciledug Cirebon mempunyai kepribadian yang baik, kompetensi yang memadai dan mampu melaksanakan tugasnya selaras dengan kepercayaan yang sudah diberikan kepadanya. Selanjutnya hasil uji validitas untuk variabel kepemimpinan dijabarkan dalam tabel berikut:

Tabel 2

Uji Validitas Variabel Kepemimpinan Perempuan

\begin{tabular}{|l|c|c|c|}
\hline No & Validitas & Angka Kritis & Keterangan \\
\hline 1. & 0,874 & 0.3 & Valid \\
\hline
\end{tabular}




\begin{tabular}{|l|l|l|l|}
\hline 2. & 0,875 & 0.3 & Valid \\
\hline 3. & 0,872 & 0.3 & Valid \\
\hline 4. & 0,870 & 0.3 & Valid \\
\hline 5. & 0,874 & 0.3 & Valid \\
\hline 6. & 0,875 & 0.3 & Valid \\
\hline 7. & 0,872 & 0.3 & Valid \\
\hline 8. & 0,838 & 0.3 & Valid \\
\hline 9. & 0,864 & 0.3 & Valid \\
\hline 10. & 0,872 & 0.3 & Valid \\
\hline
\end{tabular}

Sumber: Hasil diolah peneliti 2019

Dari tabel di atas jelas bahwa nilai r-hitung pada seluruh butir pernyataan variabel kepemimpinan perempuan (X) memperlihatkan angka yang lebih besar dari r-kritis $(0,30)$. Ini berarti bahwa bisa dinilai seluruh butir pernyataan tersebut valid dan bisa dipakai dalam penelitian. Selanjutnya hasil uji realibilitas bagi variabel kepemimpinan perempuan diuraikan dalam tabel berikut.

\section{Tabel 3}

Uji Realibilitas Variabel Kepemimpinan Perempuan

\begin{tabular}{|l|l|}
\hline \multicolumn{2}{|c|}{ Cronbach's Alpha N of Items } \\
\hline 979 & 10 \\
\hline
\end{tabular}

Berpijak pada ringkasan hasil uji reliabilitas seperti yang termuat dalam tabel 3, bisa terungkap bahwa nilai koefisien Cronbach Alpha bagi variabel kepemimpinan ialah 0,979. Ini bermakna lebih besar dari 0,6. Hal tersebut dimaknai pula bahwa seluruh item pernyataan dalam variabel penelitian ialah baik, sehingga item-item pernyataan dalam variabel penelitian bisa dipakai untuk penelitian berikutnya.

\section{Kinerja Guru}

Kinerja guru merupakan hasil kerja yang sudah diraih oleh seseorang dalam suatu organisasi untuk merealisasikan tujuan berpijak pada standarisasi atau waktu dan ukuran yang diselaraskan dengan jenis pekerjaannya dan sejalan dengan etika dan norma yang sudah ditentukan. Penjelasan mengenai hasil jawaban responden dalam menilai Kinerja Guru MTsN Ciledug Cirebon melalui sejumlah sub variabel dan meliputi beberapa indikator, yaitu:

Tabel 4

Tanggapan Responden dari Kinerja Guru

\begin{tabular}{|l|c|}
\hline \multicolumn{1}{|c|}{ Dimensi Kepemimpinan } & Nilai Rata-rata \\
\hline $\begin{array}{l}\text { 1. Kemampuan merencanakan proses belajar belajar } \\
\text { mengajar }\end{array}$ & 3.94 \\
\hline $\begin{array}{l}\text { 2. } \\
\text { Kemampuan melaksanakan dan memimpin atau } \\
\text { mengelola proses belajar mengajar }\end{array}$ & 3.74 \\
\hline
\end{tabular}




\begin{tabular}{|l|c|}
\hline 3. Kemampuan melakukan komunikasi & 3.77 \\
\hline $\begin{array}{l}\text { 4. Kemampuan menilai kemajuan proses belajar } \\
\text { mengajar }\end{array}$ & 3.94 \\
\hline 5. Kemampuan menguasai bahan pelajaran & 4.34 \\
\hline 6. Kemampuan melaksanakan pengayaan & 4.9 \\
\hline Min Skor Keseluruhan & $\underline{4.03}$ \\
\hline
\end{tabular}

Berpijak tabel di atas secara keseluruhan jawaban responden tentang kepemimpinan Kepala perempuan MTsN Ciledug Cirebon berada di level yang sangat tinggi. Hal ini memperlihatkan kepala sekolah perempuan MTsN Ciledug Cirebon sudah melakukan tugasnya dengan profesional dan baik. Kepala sekolah perempuan di MTsN Ciledug Cirebon mempunyai kepribadian yang baik, kemampuan yang handal, serta mampu melaksanakan tugasnya sejalan dengan kepercayaan yang sudah diberikan kepadanya. Hasil uji validitas untuk variabel kinerja guru diuraikan dalam tabel berikut:

Tabel 5

Uji Validitas Variabel Kinerja Guru

\begin{tabular}{|l|c|c|c|}
\hline No & Validitas & Angka Kritis & Keterangan \\
\hline 1. & 0,901 & 0.3 & Valid \\
\hline 2. & 0,894 & 0.3 & Valid \\
\hline 3. & 0,951 & 0.3 & Valid \\
\hline 4. & 0,879 & 0.3 & Valid \\
\hline 5. & 0,858 & 0.3 & Valid \\
\hline 6. & 0,955 & 0.3 & Valid \\
\hline 7. & 0,850 & 0.3 & Valid \\
\hline 8. & 0,931 & 0.3 & Valid \\
\hline 9. & 0,996 & 0.3 & Valid \\
\hline 10. & 0,862 & 0.3 & Valid \\
\hline 11. & 0,39 & 0.3 & Valid \\
\hline 12. & 0,591 & 0.3 & Valid \\
\hline 13. & 0,904 & 0.3 & Valid \\
\hline 14. & 0,819 & 0.3 & Valid \\
\hline 15. & 0,944 & 0.3 & Valid \\
\hline 16. & 0,913 & 0.3 & Valid \\
\hline 17. & 0,867 & 0.3 & Valid \\
\hline 18. & 0,858 & 0.3 & Valid \\
\hline 19. & 0,872 & 0.3 & Valid \\
\hline Sumb & Hasil & $p$ & \\
\hline
\end{tabular}

Sumber: Hasil diolah peneliti 2019

Berpijak tabel di atas menunjukkan bahwa r-hitung pada seluruh butir pernyataan variabel kinerja guru (Y) memperlihatkan angka yang lebih besar dari r-kritis $(0,30)$, sehingga bisa dapat dinilai bahwa semua butir pernyataan tersebut valid dan bisa dipakai dalam penelitian. Secara teoritis besarnya koefisien reliabilitas berkisar antara 
0,00-1,00, jika nilai Cronbachs's Alpha (r-Alpha) setidaknya 0,60, maka instrumen ukur dinilai reliabel sebab dinilai mempunyai titik aman dalam penentuan reliabilitas instrumen yang peneliti buat.

Tabel 6

Uji Realibilitas Variabel Kinerja Guru

\begin{tabular}{|l|l|}
\hline Cronbach's Alpha N of Items \\
\hline .960 & 19 \\
\hline
\end{tabular}

Berpijak pada ringkasan hasil uji reliabilitas seperti yang diuraikan pada tabel di atas, bisa terungkap bahwa nilai koefisien Cronbach Alpha bagi variabel produktivitas kerja $(\mathrm{Y}$ ) ialah 0,960, artinya lebih besar dari 0,6. Berdasarkan pada teori di atas maka seluruh item pernyataan dalam variabel penelitian ialah baik, sehingga sejumlah item pernyataan dalam variabel penelitian bisa dipakai untuk penelitian berikutnya.

3. Pengaruh Kepemimpinan Kepala Sekolah Terhadap Kinerja Guru

Guna mengunkap derajat hubungan variabel kepemimpinan perempuan (X) dan produktivitas kerja (Y), maka dipakai analisis korelasi Pearson. Mengacu pada hasil pengolahan data Microsoft SPSS 24.0 for Windows.

Tabel 7

Analisis Korelasi Ganda

\begin{tabular}{|c|l|l|l|}
\hline \multicolumn{2}{|c|}{} & $\mathrm{X}$ & $\mathrm{Y}$ \\
\hline $\mathrm{X}$ & Pearson & 1 &, $825^{*}$ \\
\hline \multirow{7}{*}{$\mathrm{Y}$} & Correlation & & \\
\cline { 2 - 4 } & $\begin{array}{l}\text { Sig. (2- } \\
\text { tailed) }\end{array}$ &, 000 \\
\cline { 2 - 4 } & $\mathrm{N}$ & 45 & 45 \\
\hline \multirow{7}{*}{$\mathrm{N}$} & Pearson &, $825^{*}$ & 1 \\
\cline { 2 - 4 } & Correlation & & \\
\cline { 2 - 4 } & $\begin{array}{l}\text { Sig. (2- } \\
\text { tailed) }\end{array}$ &, 000 & \\
\cline { 2 - 4 } & $\mathrm{N}$ & 45 & 45 \\
\hline
\end{tabular}

Nilai koefisien korelasi hubungan antar variabel kepemimpinan kepala sekolah perempuan (X) dengan kinerja guru (Y) ialah sebesar 0,825. Nilai koefisien korelasi hubungan antar variabel kepemimpinan kepala sekolah perempuan (X) dengan kinerja guru (Y) ialah sebesar 0,825. Ini berarti level interpelasi koefisien korelasi pengaruh kepemimpinan kepala sekolah perempuan terhadap kinerja guru pada MTsN Ciledug Cirebon ialah sangat kuat dengan interval koefisien 0,80 - 1,000. Sementara itu, arah hubungan ialah positif karena nilai $r$ positif. Ini berarti bahwa apabila kepemimpinan 
Asep Kurniawan

kepala sekolah perempuan baik maka kinerja guru akan semakin baik begitu pula sebaliknya.

Dalam usaha untuk mengungkap sejauh mana kontribusi variabel $X$ (kepemimpinan kepala sekolah perempuan) terhadap variabel Y (kinerja guru), maka dipakai formula Koefisien Penentu (KP), yaitu:

$$
\begin{aligned}
K P & =\mathrm{r}^{2} \mathrm{X} 100 \% \\
& =(0,825 \times 0,825) \times 100 \% \\
& =68.0625 \%
\end{aligned}
$$

Hal tersebut memperlihatkan bahwa kepemimpinan kepala sekolah perempuan (X) mempengaruhi sebesar 68,0625\% terhadap kinerja guru (Y) pada MTsN Ciledug Cirebon, sedangkan 31,9375\% diperanguhi oleh faktor lain di luar penelitian ini.

Dari semua hasil kegiatan penelitian yang sudah dilaksanakan, maka bisa ditarik kesimpulan, yaitu Kepemimpinan Kepala sekolah perempuan MTsN Ciledug Cirebon telah baik sehingga kinerja guru pun berakibat baik. Apabila dipersentasekan 68,0625\% pengaruh dari kepemimpinan kepala sekolah perempuan ini terhadap kinerja guru. Hal tersebut diakibatkan oleh kepemimpinan kepala sekolah perempuan memiliki arti agar guru tidak keluar dari jalur yang telah ditetapkan oleh aturan yang ada.

Hasil penelitian diatas menunjukkan bahwa kepala sekolah mempengaruhi mutu sekolah melalui kinerja guru. Meskipun mutu sekolah masih banyak ditentukan oleh komponen-komponen manajemen yang lain. Hasil dari penelitian ini sekaligus juga mendukung banyak penelitian yang mengungkapkan bahwa kualitas kepemimpinan pada kualitas pendidikan dalam berbagai dimensinya. Dimensi yang dimaksud bisa berupa pengaruh terhadap prestasi belajar (Cruickshank, 2017: 115), iklim pendidikan di sekolah (Jabari, 2014:2; Ngang, 2011:2575), terutama dengan kinerja guru (Shamaki, 2015:200). Hasil penelitian ini juga didukung hasil riset bahwa mengungkapkan bahwa kepemimpinan dalam sekolah sangat penting, sebab pada hakekatnya sekolah merupakan lembaga yang memegang peranan penting dalam menentukan mutu pendidikan (Baporikar, 2015:320). Secara khusus penelitian ini mendukung hasil penelitian yang mengungkapkan bahwa kepemimpinan perempuan berpengaruh terhadap kualitas pendidikan. Temuan Oyeniran dan Anchomese (2014:148-173) di Negara Pantai Gading menunjukkan bahwa perempuan memengaruhi komitmen guru secara langsung dan secara tidak langsung juga proses belajar siswa, terutama mereka 
yang mengalami kesulitan belajar. Data juga mengungkapkan bahwa perempuan ini digunakan untuk menciptakan lingkungan dan dukungan akademis yang memberikan perhatian kepada anak-anak, karena kondisi belajar ini mirip dengan kehidupan mereka yang sebenarnya di rumah. Berdasarkan temuan, kami mengasumsikan bahwa kepemimpinan perempuan dapat menjadi kontribusi yang signifikan untuk kualitas belajar siswa, yang pada gilirannya mempengaruhi secara positif peningkatan sekolah. Itu bahkan konsisten dengan literatur, yang tetap konstan dalam pernyataan bahwa pemimpin wanita memiliki beberapa kemampuan, seperti menjadi perhatian, perhatian, sabar. Dalam hal ini, praktisi pendidikan, pembuat kebijakan dan pemangku kepentingan harus lebih memperhatikan kepala sekolah dasar wanita untuk memberdayakan mereka untuk menampilkan pengetahuan mereka, keahlian dan bakat yang berguna untuk proses belajar siswa. Itu tampaknya cadangan yang mungkin untuk sistem pendidikan Pantai Gading untuk mengurangi prestasi akademik yang rendah dan meningkatkan kinerja sekolah.

\section{CONCLUSION}

Kinerja Guru di MTsN Ciledug dipengaruhi oleh kepemimpinan yang dimiliki kepala sekolah perempuan. Ini artinya bahwa semakin efektif kepemimpinan yang dilakukan oleh kepala sekolah perempuan maka akan semakin tinggi kinerja guru, begitu pula sebaliknya semakin kurangnya kepemimpinan seorang kepala sekolah perempuan, maka kinerja guru tersebut juga dengan sendirinya akan menurun. Simpulan ini dilandaskan pada hasil penelitian, dimana ada pengaruh yang signifikan kepemimpinan kepala sekolah perempuan di MTsN Ciledug terhadap kinerja guru.

\section{REFERENCES}

Baporikar, Neeta. (2015). "Educational Leadership for Enhancing Quality in Teacher Education". Nwachukwu Prince Ololube, Peter James Kpolovie, Lazarus Ndiku Makewa, Handbook of Research on Enhancing Teacher Education with Advanced Instructional Technologies. Hershey PA, USA: IGI Global book, 320-341.

Carli, L. L. (1999). "Gender, Interpersonal Power, and Social Influence”. Journal of Social, 55 (1), 81-99.

Channar, Zahid Ali, Zareen Abbassi, Imran Anwar Ujan. (2011). "Gender Discrimination in Workforce and its Impact on the Employees." Pak. J. Commer. Soc. Sci, 5 (1), 177-191.

Cruickshank, Vaughan. (2017). "The Influence of School Leadership on Student Outcomes". Open Journal of Social Sciences, 05(09), 115-123.

Engels, Nadine, Gwendoline Hotton, Geert Devos, Dave Bouckenooghe. (2018). "Principals in Schools with a Positive School Culture". Educational Studies, 34 (3), 159-174.

Frankel, Lois P. (2007). See Jane Lead: 99 Kiat Sukses Memimpin Bagi Perempuan. Jakarta: Gramedia Pustaka Utama. 
Fischbach, Andrea, Philipp Wolfgang Lichtenthaler. (2015). "Leadership and Gender Stereotyping of Emotions". Journal of Personnel Psychology, 14(3), 153-162.

Gewasari, Miska, Belferik Manullang, Abdul Muin Sibuea. (2017). "The Determinant Factors that Effect Teacher Performance of Public Senior High School in Deli Serdang District". Journal of Research \& Method in Education, 7(1), 12-21.

Gupton, Sandra Lee. (2009). "Women in Educational Leadership in the U.S.: Reflections of a 50 Year Veteran". Forum on Public Policy, 1-20.

Halilah. (2010). "Women's Leadership in Educational Management". Management Journal of Education, 1, 1-9.

Hayati, Neuneung Ratna. (2009). "Faktor-faktor yang Mempengaruhi Kemampuan Kaum Perempuan dalam Kepemimpinan”. Seminar Nasional Wanita, Pusat Studi Wanita UGM, 214-218.

Hejase, Hussin, Ziad Haddad, Bassam Hamdar, Rasha Massoud, Rasha Massoud, George Farha. (2013). "Female Leadership: An Exploratory Research from Lebanon". American Journal of Scientific Research, 86, 28-52.

Hunawa, Robby. (2018). "Penguatan Gender dalam Pengambilan Keputusan Birokrasi di Kabupaten Bone Bolango". Gorontalo-Journal of Government and Political Studies, 1 (1), 24-39.

Jabari, Basel al-. (2014). "The Influence of Effective Leadership on School Climate". SSRN Electronic Journal, 3 (26), 1-35.

Johnson, S. K., Murphy, S. E., Zewdie, S., Reichard, R. J. (2008). "The Strong, Sensitive Type: Effects of Gender Stereotypes and Leadership Prototypes on the Evaluation of Male and Female Leaders". Organizational Behavior and Human Decision Processes, 106, 39-60.

Kiprop, Catherine. (2016). "Principal's Leadership Practices in the Management of Discipline in Public Secondary Schools in Kenya in the Post-Caning Era". International Journal of Research in Management, 6(6), 17-32.

Kurniawan, Asep. (2018). Metodologi Penelitian Pendidikan. Bandung: Rosdakarya.

Ngang, Tang Keow. (2011). "The Effect of Transformational Leadership on School Culture in Male' Primary Schools Maldives”. Procedia - Social and Behavioral Sciences, 30, 2575-2580.

Noor, J. (2011). Metodologi Penelitian. Jakarta: Kencana Prenada Media Group

Nurlina. (2015). "Model Kepemimpinan Dalam Karakteristik Gender". Jurnal An-Nisa', 8 (1), 169.

Oyeniran, Rassidy, Ishmael Bonjah Anchomese. (2014). “Women's Leadership Experiences: A Study of Ivorian Women Primary School Principals". Journal of Educational Issues, 4 (1), 148-173.

Rosida, Ida, Lestari Rejeki. (2017). "Woman in Patriarchal Culture: Gender Discrimination and Intersectionality Portrayed in Bob Darling by Carolyn Cooke". INSANIYAT Journal of Islam and Humanities, 1(2), 129-139.

Shamaki, E. B. (2015). "Influence of Leadership Style on Teacher's Job Productivity in Public Secondary Schools in Taraba State, Nigeria". Journal of Education and Practice, 6 (10), 200-203.

Undang-Undang Nomor 20 Tahun 2003 tentang Sistem Pendidikan Nasional

Underdahl, Samantha C. Paustian-, Lisa Slattery Walker and David J. Woehr. (2014). "Gender and Perceptions of Leadership Effectiveness: A Meta-Analysis of Contextual Moderators." Journal of Applied Psychology, 99(6), 1129 -1145.

Werang, Basilius Redan. (2014). "Relationship between Principal's Leadership, School Organizational Climate, and Teachers' Job Performance at State Senior High School in Merauke Regency, Papua, Indonesia". International Journal of Education and Research, 2 (6), 635-640. 
Asep Kurniawan

Văcar, Anca dan Dan Miricescu. (2013). "Leadership - A Key Factor to a Succesful Organization". Procedia Economics and Finance, 6, 430-435. 